\title{
Analisis pendapatan usaha kecil dan menengah di Kabupaten Tanjung Jabung Barat (studi kasus usaha keripik tempe di Desa Serdang Jaya Kecamatan Betara)
}

\author{
Nur Abni Yusmah, *Yulmardi, Adi Bhakti \\ Prodi Ekonomi Pembangunan, Ekonomi dan Bisnis, Universitas Jambi \\ Email Korespondensi: yulmardiedy@yahoo.co.id
}

\begin{abstract}
The purpose of this study is to determine and analyze the socio-economic characteristics of tempe chip business in Serdang Jaya Village, Betara District and the effect of production, production costs and labor use on the income of tempe chip business in Serdang Jaya Village, Betara District. The data used in this study are secondary data. The analytical method used is quantitative descriptive analysis. The analytical tool used is multiple linear regression. The results showed the effect of production (PRO), production costs (BP) and the use of labor (PTK) together or partially had an influence on the income of tempe chip entrepreneurs in Serdang Jaya Village $(Y)$ at a significance level of $5 \%$.
\end{abstract}

Keywords: Revenue, Industry, Tempe, Chips, Business

\begin{abstract}
Abstrak
Adapun yang menjadi tujuan dari penelitian ini adalah untuk mengetahui dan menganalisis karakteristik sosial ekonomi usaha keripik tempe di Desa Serdang Jaya Kecamatan Betara serta pengaruh produksi, biaya produksi dan penggunaan tenaga kerja terhadap pendapatan usaha keripik tempe di Desa Serdang Jaya Kecamatan Betara. Data yang digunakan dalam penelitian ini merupakan data sekunder. Metode analisis yang digunakan adalah analisis deskriptif kuantitatif. Alat analisis yang digunakan adalah regresi linier berganda. Hasil penelitian menunjukkan variabel pengaruh produksi (PRO), biaya produksi (BP) dan penggunaan tenaga kerja (PTK) secara bersama-sama maupun parsial memiliki pengaruh terhadap pendapatan pengusaha keripik tempe di Desa Serdang Jaya (Y) pada tingkat signifikansi 5\%.
\end{abstract}

Kata Kunci: Pendapatan, Industri, Tempe, Keripik, Usaha

\section{PENDAHULUAN}

Kedelai dapat dimanfaatkan untuk membuat tahu, tempe, kecap, susu kedelai, tepung kedelai, minyak kedelai dan tauco. Hasil olahan berbahan kedelai merupakan makanan sehat yang mengandung protein tinggi, karbohidrat, lemak, mineral serta vitamin.

Menurut Tasman (2006), produksi adalah proses kombinasi dan koordinasi material dan kekuatan (input, faktor, sumberdaya, atau jasa produksi) dalam pembuatan suatu barang atau jasa output atau produk.Kabupaten Tanjung Jabung Barat merupakan salah satu penghasil kedelai. Menurut Tanjung Jabung Barat dalam Angka (2018), 
produksi kedelai pada tahun 2017 sama sekali tidak ada panen pada tahun tersebut. Berbeda dengan pada tahun 2016 dimana Kabupaten Tanjung Jabung Barat mampu memproduksi sebanyak 68 ton pada tahun tersebut. Tidak adanya produksi kedelai juga terjadi pada tahun 2015 padahal pada tahun 2014 jumlah produksi kedelai sebanyak 317 ton yang mengalami peningkatan dari tahun 2013 sebanyak 204 ton. Hal ini berarti jumlah produksi kedelai Kabupaten Tanjung Jabung Barat mengalami penurunan.

Menurut Betara dalam Angka (2018), Kecamatan Betara merupakan salah satu kecamatan yang tidak memproduksi kedelai pada tahun 2013 sampai 2018 termasuk Desa Serdang Jaya. Desa Serdang Jaya merupakan salah satu desa di Kecamatan Betara yang terkenal akan hasil panen perkebunannya antara lain karet, kelapa, kelapa sawit, kopi dan pinang. Walaupun bukan desa yang memproduksi kedelai, Desa Serdang Jaya mampu menjadi salah satu sentra industri yang menggunakan kedelai sebagai bahan baku industri pengolahan makanan yang mampu menjadi sumber pendapatan bagi masyararakat di desa tersebut. Pendapatan merupakan unsur yang sangat penting dalam sebuah usaha perdagangan, karena dalam melakukan suatu usaha tentu ingin mengetahui nilai atau jumlah pendapatan yang diperoleh selama melakukan usaha tersebut (Paula dalam Artaman, 2015).

Rusanti (2014) meneliti tentang Determinan Pendapatan Usaha Mikro, Kecil, dan Menengah (UMKM) Sektor Industri Pengolahan di Kabupaten Jember. Alat analisis yang digunakan adalah regresi linier berganda. Hasil penelitian menunjukkan bahwa secara simultan modal awal, hutang, total asset, inovasi, proaktif, dan risk taking berpengaruh signifikan terhadap pendapatan UMKM sektor industry pengolahan sedangkan modal awal, inovasi dan risk taking berpengaruh positif namun tidak signifikan terhadap pendapatan UMKM sektor industri pengolahan di Kabupaten Jember. Ma'arif (2013) meneliti tentang Analisis Faktor-Faktor yang mempengaruhi Pendapatan Pedagang Pasar Bandarjo Ungaran Kabupaten Semarang. Alat analisis yang digunakan adalah regresi linier berganda. Hasil Penelitian menunjukkan variabel modal, lokasi dagang, kondisi tempat berdagang secara simultan (bersama-sama) dan parsial berpengaruh signifikan terhadap pendapatan pedagang pasar Bandarjo Ungaran Kabupaten Semarang. Asruni (2012) meneliti tentang factor-faktor yang mempengaruhi usaha kecil dan menengah (UKM) di Kabupaten Hulu Sungai Selatan Provinsi Kalimantan Selatan. Alat analisis yang digunakan adalah regresi linier berganda. Hasil penelitian menunjukkan bahwa pemasaran, financial, SDM, produksi, teknologi, proses dan bukti fisik secara simultan dan parsial berpengaruh signifikan terhadap pendapatan di UKM Kabupaten Hulu Sungai Selatan.

Salah satu hasil industri pengolahan kedelai di Desa Serdang Jaya adalah keripik tempe. Keripik tempe merupakan tempe tipis yang digoreng kering seperti keripik, teksturnya kering dan keras. Tempe yang digunakan dapat berasal dari tempe yang sudah di potong tipis. Apabila disimpan di tempat kering dan bersih, keripik tempe dapat bertahan hingga beberapa minggu denga cara dimasukkan ke kantor plastic atau kaleng yang tertutup rapat dan tidak terpengaruh udara lembab.

Menurut Kepala Kantor Desa Serdang Jaya, industri keripik tempe di Desa Serdang Jaya mengalami peningkatan dari tahun 2017 yang hanya ada 12 pengusaha keripik tempe meningkat menjadi 20 pengusaha keripik tempe pada tahun 2018. Usaha keripik tempe ini menurutnya cukup menjanjikan mengingat keripik tempe yang enak 
sebagai makanan cemilan juga sebagai makanan pendamping nasi. Usaha keripik tempe juga mampu mengurangi pengangguran walaupun tidak dalam jumlah yang banyak karena usaha ini dapat menyerap tenaga kerja walaupun tenaga kerjanya biasanya berasal dari dalam keluarga.

Menurut Bapak Mukamin (salah satu pengusaha keripik tempe yang penulis wawancarai). Modal awal usaha keripik tempe adalah sebesar lima juta rupiah dimana modal tersebut didapat dari pinjaman bank. Modal tersebut digunakan untuk membeli perlengkatan, perlengkapan serta bahan baku pembuatan keripik tempe. Proses pembuatan keripik tempe paling banyak menghabiskan 3 - 3,5 kilogram tempe. Keripik tempe dari hasil pengolahan tempe dititipkan ke toko-toko maupun warung kopi untuk dijual. Omset yang diraup dari hasil penjualan keripik tempe adalah sebesar 50-80 ribu rupiah per harinya. Omset ini menurutnya dapat mencukupi kebutuhan hidup sehari-hari dan dijadikan sebagai biaya variabel untuk pembuatan keripik tempe hari berikutnya. Bahkan dengan omset yang didapat sanggup untuk mencicil pinjaman dan bunga bank per bulannya.

Kabupaten Tanjung Jabung Barat memiliki Kecamatan yang merupakan sentra industri keripik tempe. Kecamatan tersebut adalah Kecamatan Betara. Salah satu desa yang memproduksi keripik tempe adalah Desa Serdang Jaya. Industri keripik tempe di Desa Serdang Jaya merupakan industri rumah tangga yang sebagian besar pekerjanya adalah berasal dari dalam keluarga dan menggunakan modal sendiri. Proses pembuatan keripik tempe di Desa Serdang Jaya masih tergolong tradisional. Walaupun begitu, produk keripik tempe yang dibuat di Desa Serdang Jaya telah menjadi cemilan yang cukup populer di Kabupaten Tanjung Jabung Barat. Sebab, selain sebagai cemilan keripik tempe juga dijadikan sebaik lauk pendamping untuk nasi yang merupakan makanan pokok masyarakat Kabupaten Tanjung Jabung Barat.

Adapun tujuan dari penelitian ini adalah 1) Mengetahui dan menganalisis karakteristik sosial ekonomi pengusaha keripik tempe; 2) Mengetahui dan menganalisis pengaruh modal usaha, lama usaha dan lokasi usaha terhadap pendapatan pengusaha keripik tempe di Desa Serdang Jaya Kecamatan Betara.

\section{METODE}

\section{Jenis dan sumber data}

Jenis data yang digunakan dalam penelitian ii adalah data sekunder yang bersumber dari kuesioner yang disebarkan oleh penulis ke responden. Responden penelitian adalah para pengusaha keripik sebanyak 20 populasi sekaligus merupakan sample penelitian yang berada di Desa Serdang Jaya Kecamatan Betara. Menurut Sugiyono (2011), Populasi adalah wilayah generalisasi yang terdiri atas objek atau subjek yang mempunyai kualitas dan karakteristik tertentu yang ditetapkan oleh peneliti untuk dipelajari dan kemudian ditarik kesimpulannya. Daerah penelitian yang dipilih yaitu Desa Serdang Jaya Kecamatan Betara dengan secara sengaja (purposive). Pertimbangan daerah tersebut dijadikan sebagai lokasi penelitian adalah Desa Serdang Jaya merupakan sentra industri keripik tempe di Kecamatan Betara. 


\section{Metode analisis data}

Metode yang digunakan dalam penelitian ini adalah metode analisis deskriptif dan analisis kuantitatif. Analisis Deskriptif sangat bermanfaat untuk menganalisis data populasi atau untuk menganalisis kajian atau penelitian yang obyeknya berupa populasi. Analisis Deskriptif adalah suatu metode yang berfungsi untuk membuat gambaran secara sistematis dan faktual mengenai fakta-fakta yang ada dilapangan dengan berdasarkan kepada teori-teori, konsep-konsep, yang ada diliteratur yang terkait dengan penelitian ini. Dimana prosedur gejala dan hubungan-hubungannya didefinisikan, diklasifikasikan, dan dikategorikan (Amir, dkk, 2009). Analisis kuantitatif lebih mampu menghasilkan hasil yang cermat. Perhitungan dan analisis matematis, bagaimanapun juga adalah kegiatan yang dituntun secara sadar oleh disiplin, kecermatan dan ketelitian. Namun demikian hendaklah tetap ingat bahwa kelebihan dalam hal kecermatan (accuracy) ini tidaklah berarti bahwa pada analisis kuantitatif itu selalu ada kelebihan dalam hal derajat kebenarannya (validity) apabila pengolahan data, penggunaan data tidak tepat (Amir, dkk, 2009).

Alat analisis yang digunakan adalah metode regresi linier berganda. Regresi linier berganda digunakan untuk melihat pengaruh antara dua atau lebih variabel bebas terhadap satu variabel terikat. Untuk menganalisis keadaan sosial ekonomi pengusaha Keripik tempe di Desa Serdang Jaya Kecamatan Betara Kabupaten Tanjung Jabung Barat digunakan metode deskriptif dengan menggunakan 20 responden sebagai sample yang juga merupakan populasi. Untuk menganalisis pengaruh modal usaha, lama usaha dan lokasi usaha maka digunakan rumus regresi linier berganda dalam bentuk persamaan sebagai berikut (Firdaus,2011):

$$
\mathrm{Y}=\mathrm{a}+\mathrm{b}_{1} \mathrm{X}_{1}+\mathrm{b}_{2} \mathrm{X}_{2}+\ldots \ldots . \mathrm{b}_{\mathrm{n}} \mathrm{X}_{\mathrm{n}}
$$

Selanjutnya model analisis regresi linier berganda tersebut ditransformasikan secara operasional sesuai dengan variabel penelitian sebagai berikut:

$$
\boldsymbol{Y}=\boldsymbol{\beta}_{0}+\boldsymbol{\beta}_{1} \text { Pro }+\boldsymbol{\beta}_{2} \mathrm{BV}++\boldsymbol{\beta}_{3} \mathrm{TK}+\mu
$$

Keterangan:

$$
\begin{array}{ll}
\mathrm{Y} & =\text { Pendapatan Pengusaha Keripik tempe (Rp) } \\
\text { Pro } & =\text { Produksi (Bungkus) } \\
\mathrm{BV} & =\text { Biaya Variabel (Rp) } \\
\mathrm{TK} & =\text { Penggunaan Tenaga Kerja (Dummy) } \\
\beta_{0} & =\text { konstanta } \\
\beta_{1}, \beta_{2}, \beta_{3} & =\text { koefisien } \\
\mu & =\text { disturbance term }
\end{array}
$$

\section{HASIL DAN PEMBAHSAN \\ Karakteristik sosial ekonomi \\ Karakteristik usaha keripik tempe berdasarkan usia}

Usia pengusaha merupakan ukuran kemampuan dalam membuat Keripik tempe dalam proses pembuatan keripik tempe. Semakin muda usia seorang pengusaha maka pengusaha tersebut akan semakin produktif, sebaliknya semakin tua usia seorang pengusaha maka pengusaha tersebut akan semakin tidak produktif. Dikatakan demikian karena tenaga dan stamina pengusaha keripik tempe yang umurnya lebih muda lebih besar dibandingkan dengan tenaga dan stamina pengusaha keripik tempe yang umurnya 
lebih tua. Kelompok usia pengusaha keripik tempe di Kecamatan betara Kecamatan Kuala Betara adalah sebagai berikut:

Tabel 1. Persentase responden menurut kelompok umur di Kecamatan Betara

\begin{tabular}{crrr}
\hline $\begin{array}{c}\text { Usia } \\
\text { (Tahun) }\end{array}$ & $\begin{array}{c}\text { Jumlah } \\
\text { (Orang) }\end{array}$ & \multicolumn{2}{c}{$\begin{array}{c}\text { Persentase } \\
(\boldsymbol{\%})\end{array}$} \\
\hline $27-38$ & & 7 & 35,00 \\
$39-50$ & 10 & 50,00 \\
$51-62$ & 1 & 5,00 \\
$63-74$ & 2 & 10,00 \\
Total & 20 & 100,00 \\
\hline
\end{tabular}

Sumber: Data Primer, 2017

Tabel 1 memperlihatkan bahwa umur terbanyak adalah pada umur 39-50 yaitu sebanyak 10 orang atau $50 \%$. Sedangkan distribusi umur terendah adalah 51-62 tahun yaitu sebanyak 1 orang atau $5 \%$.

\section{Karakteristik usaha keripik tempe berdasarkan tingkat pendidikan}

Tingkat pendidikan pengusaha keripik tempe merupakan tingkat pendidikan jenjang terakhir yang telah diselesaikan pengusaha keripik tempe yang berada di Kecamatan betara Kecamatan Kuala Betara. Tingkat pendidikan pengusaha Keripik tempe akan mempengaruhi kemampuan pengusaha tersebut dalam menganalisa suatu persoalan yang berkaitan dengan Keripik tempe sehingga akan mempengaruhi produktivitas dari usaha Keripik tempe tersebut. Kerincian tingkat pendidikan pengusaha keripik tempe tersebut dapat dilihat pada tabel 2:

Tabel 2 Persentase responden menurut tingkat pendidikan di Kecamatan Betara

\begin{tabular}{ccrr}
$\begin{array}{c}\text { Tingkat } \\
\text { Pendidikan }\end{array}$ & $\begin{array}{c}\text { Jumlah } \\
\text { (Orang) }\end{array}$ & \multicolumn{2}{c}{$\begin{array}{c}\text { Persentase } \\
(\boldsymbol{\%})\end{array}$} \\
\hline SD & & 4 & 20,00 \\
SMP & 2 & 10,00 \\
SMA & 11 & 55,00 \\
S1 & 3 & 15,00 \\
Total & 20 & 100,00 \\
\hline
\end{tabular}

Sumber: Data Primer, 2017

Berdasarkan pengamatan di lapangan diketahui bahwa sebagian besar pengusaha keripik tempe di Kecamatan betara yang terbanyak adalah tamatan SMA yaitu sebanyak 11 orang atau 55\%. Sedangkan yang terendah adalah tamat SMP yaitu sebanyak 2 orang atau $10 \%$. Tamatan S1 hanya sebanyak 3 orang atau sekitar $15 \%$ sedangkan Tamatan SD sebanyak 4 orang atau $20 \%$.

\section{Karakteristik usaha keripik tempe berdasarkan jumlah anggota keluarga}

Anggta keluarga merupakan tanggung jawab dari kepala keluarga muali dari segi pemenuhan kebutuhan hidup sampai kebutuha psikologis dan biologis. Anggota keluarga yang semakin banyak akan mempertinggi biaya tanggungan yang harus ditanggung oleh kepala keluarga disamping itu, biaya produksi Keripik tempe dapat 
ditekan apalagi anggota keluarga berpartisipasi dalam proses produksi. Distribusi frekuensi pengusaha keripik tempe di Kecamatan betara dapat dilihat pada tabel 3:

Tabel 3 Persentase responden menurut jumlah anggota keluarga di Kecamatan Betara

\begin{tabular}{crrr}
$\begin{array}{c}\text { Jumlah Anggota Keluarga } \\
\text { (Orang) }\end{array}$ & $\begin{array}{c}\text { Jumlah } \\
\text { (Orang) }\end{array}$ & \multicolumn{2}{c}{$\begin{array}{c}\text { Persentase } \\
(\%)\end{array}$} \\
\hline $2-3$ & & 7 & 35,00 \\
$4-5$ & 10 & 50,00 \\
$6-7$ & 3 & 15,00 \\
Total & 20 & 100,00 \\
\hline
\end{tabular}

Sumber: Data Primer,2017

Berdasarkan tabel 3 terlihat bahwa jumlah anggota terbanyak adalah 4-5 orang yaitu sebanyak 10 orang atau sebanyak $50 \%$. Sedangkan jumlah anggota paling sedikit adalah 6-7 orang sebanyak 3 orang atau $15 \%$.

\section{Karakteristik usaha keripik tempe berdasarkan pengalaman kerja}

Pengalaman kerja merupakan ukuran pengalaman para pengusaha keripik tempe yang telah menggeluti bidang usaha perkebunan Keripik tempe. Pengalaman kerja yang makin lama berarti pengetahuan para pengusaha keripik tempe juga akan berkembang sehingga produksi Keripik tempe juga akan meningkat. Distribusi frekuensi pengalaman kerja di Kecamatan betara dapat dilihat pada tabel 4:

Tabel 4 Persentase responden menurut pengalaman kerja di Kecamatan Betara

\begin{tabular}{ccrr}
\hline $\begin{array}{c}\text { Pengalaman kerja } \\
\text { (Tahun) }\end{array}$ & $\begin{array}{c}\text { Jumlah } \\
\text { (Orang) }\end{array}$ & \multicolumn{2}{c}{$\begin{array}{c}\text { Persentase } \\
(\boldsymbol{\%})\end{array}$} \\
\hline $5-8$ & & 12 & 60,00 \\
$9-12$ & 1 & 5,00 \\
$13-16$ & 1 & 5,00 \\
$17-20$ & 3 & 15,00 \\
$21-24$ & 2 & 10,00 \\
$25-28$ & 1 & 5,00 \\
Total & 20 & 100,00 \\
\hline
\end{tabular}

Sumber: Data Primer, 2017

Berdasarkan tabel 4, pengalaman kerja paling lama adalah 25-28 tahun hanya sebanyak 1 orang atau 5\% sedangkan pengalaman bertani paling sedikit adalah 5-8 tahun sebanyak 12 orang atau 60\%. Pengalaman kerja 25-28 tahun tentu saja akan memiliki produktivitas yang lebih tingi dibandingkan dengan pengalaman 5-8 tahun. Hal ini dikarenakan semakin tinggi pengalaman maka pengetahuan dan skill dalam mengolah bahan baku tempe menjadi keripik akan meningkat yang menyebabkan meningkatknya produktivitas usaha keripik tempe. Peningkatan produktivitas usaha keripik tempe selanjutnya akan meningkatkan tingkat pendapatan pengusaha keripik tempe. 


\section{Karakteristik usaha keripik tempe berdasarkan produksi}

Produksi keripik tempe merupakan jumlah keripik tempe yang mampu diproduksi atau dihasilkan oleh para pengusaha keripik tempe setiap bulannya di Kecamatan betara. Hasil produksi yang diperoleh para pengusaha keripik tempe di desa tersebut bervariasi. Hal ini disebabkan karena pengaruh ketersediaan modal, bahan baku dan waktu. Akibat dari faktor tersebut membuat hasil produksi keripik tempe bervariasi dari segi rasa maupun kemasan. Distribusi frekuensi produksi Keripik tempe dapat dilihat pada tabel 5 .

Tabel 5 Persentase responden menurut produksi keripik tempe di Kecamatan Betara

\begin{tabular}{ccrr}
\hline $\begin{array}{c}\text { Produksi keripik tempe } \\
\text { (bungkus) }\end{array}$ & $\begin{array}{c}\text { Jumlah } \\
\text { (Orang) }\end{array}$ & \multicolumn{2}{c}{$\begin{array}{c}\text { Persentase } \\
(\%)\end{array}$} \\
\hline $1.350-1.700$ & & 4 & 20,00 \\
$1.701-2.050$ & 6 & 30,00 \\
$2.051-2.400$ & 0 & 0,00 \\
$2.401-2.750$ & 6 & 30,00 \\
$2.751-3.100$ & 4 & 20,00 \\
Total & 20 & 100,00 \\
\hline
\end{tabular}

Sumber: Data Primer, 2017

Berdasarkan tabel 5, produksi Keripik tempe paling sedikit sebanyak 1350-1700 berjumlah 4 orang atau 20\%. Sedangkan produksi Keripik tempe terbanyak adalah 2751-3100 sebanyak 6 orang atau 30\%.

\section{Pendapatan usaha keripik tempe di Kecamatan Betara}

Pendapatan pengusaha keripik tempe di Kecamatan betara merupakan penghasilan yang diperoleh pengusaha keripik tempe yang berasal dari hasil produksi Keripik tempe yang kemudian dijual oleh para pengusaha. Distribusi frekuensi pendapatan pengusaha keripik tempe di Kecamatan betara dapat dilihat pada tabel 6 .

Tabel 6 Persentase responden menurut pendapatan pengusaha keripik tempe

\begin{tabular}{ccrr}
\hline $\begin{array}{c}\text { Pendapatan } \\
(\text { Rp/bulan) }\end{array}$ & $\begin{array}{c}\text { Jumlah } \\
\text { (Orang) }\end{array}$ & \multicolumn{2}{c}{$\begin{array}{c}\text { Persentase } \\
(\boldsymbol{\%})\end{array}$} \\
\hline $12.500 .000-14.000 .000$ & & 9 & 45,00 \\
$14.000 .001-15.500 .000$ & & 4 & 20,00 \\
$15.500 .001-17.000 .000$ & 2 & & 10,00 \\
$17.000 .001-18.500 .000$ & 3 & & 15,00 \\
$18.500 .001-20.000 .000$ & 2 & 10,00 \\
Total & 20 & 100,00 \\
\hline
\end{tabular}

Sumber: Data Primer, 2017

Berdasarkan tabel 6 , terlihat bahwa pengusaha keripik tempe dengan penghasilan terendah antara Rp. 12.500.000- Rp. 14.000.000 adalah sebanyak 9 orang atau sekitar 45\%. Penghasilan tertinggi antara Rp. $18.500 .001-$ Rp. 20.000 .000 hanya 2 atau sekitar $10 \%$

\section{Hasil regresi linier berganda}

Regresi linier berganda digunakan sebagai alat untuk mengetahui pengaruh pengaruh produksi (PRO), biaya produksi (BP) dan penggunaan tenaga kerja (PTK) 
terhadap pendapatan pengusaha keripik tempe di Kecamatan Betara (Y). Regresi linier berganda digunakan karena terdapat lebih dari satu variabel bebas (Independent Variable) terhadap 1 variabel terikat (Dependent Variabel). Variabel bebas yang terdapat pada penelitian ini adalah sedangkan variabel terikat dalam penelitian ini adalah pendapatan pengusaha keripik tempe di Kecamatan Betara (Y). Hasil regresi linier berganda dapat dilihat pada produksi (PRO), biaya produksi (BP) dan penggunaan tenaga kerja (PTK) tabel 7:

Tabel 7. Hasil regresi linier berganda

\begin{tabular}{crrrr}
\hline Variable & Coefficient & Std. Error & \multicolumn{1}{c}{ t-Statistic } & \multicolumn{1}{c}{ Prob. } \\
\hline C & -31034922 & 5812335. & -5.339493 & 0.0001 \\
PRO & 3879.163 & 749.1835 & 5.177854 & 0.0001 \\
BP & 2.823281 & 0.322631 & 8.750817 & 0.0000 \\
PTK & 954569.2 & 412981.4 & 2.311410 & 0.0345 \\
R-squared & 0.864842 F-statistic & 34.12656 \\
& \multicolumn{2}{c}{ Prob(F-statistic) } & 0.000000 \\
\hline
\end{tabular}

Sumber:Pengolahan Data dengan Eviews 7

Berdasarkan tabel 9, persamaan regresi linier berganda yang diperoleh dengan pengolahan data menggunakan eviews 7 adalah:

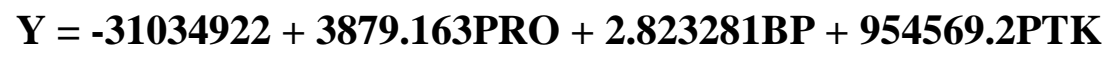

Persamaan regresi tersebut dapat diinterprestasikan bahwa apabila variabel produksi (PRO), biaya produksi (BP) dan penggunaan tenaga kerja (PTK) bersifat tetap atau tidak berubah maka pendapatan pengusaha keripik tempe di Kecamatan betara (Y) akan menurun sebesar 31.034.922 rupiah. Berdasarkan persamaan regresi tersebut diperoleh koefisien determinasi $\left(\mathrm{R}^{2}\right)$ adalah 0.864842 . Hal ini berarti bahwa sebesar 86,48 \% variabel pendapatan pengusaha keripik tempe di Kecamatan Betara (Y) mampu dijelaskan oleh variabel produksi (PRO), biaya produksi (BP) dan penggunaan tenaga kerja (PTK) sedangkan 13,52 \% dijelaskan oleh variabel lain diluar model.

\section{Uji-F}

Uji-F digunakan untuk melihat pengaruh variabel bebas dalam mempengaruhi variabel terikat secara serentak atau bersama-sama. Berdasarkan hasil regresi linier berganda pada tabel 5.9 didapat probabilitas F-Statistik adalah 0.000 dimana nilai ini lebih kecil dibandingkan dengan tingkat signifikansi 5\%. Hal ini berarti secara serentak atau bersama-sama variabel bebas (variabel produksi (PRO), biaya produksi (BP) dan penggunaan tenaga kerja (PTK)) memiliki pengaruh terhadap variabel terikat (pendapatan pengusaha keripik tempe di Kecamatan (Y)).

Uji-t

Uji-t digunakan untuk menganalisis pengaruh setiap variabel independen (variabel produksi (PRO), biaya produksi (BP) dan penggunaan tenaga kerja (PTK)) terhadap variabel terikat (pendapatan pengusaha keripik tempe di Kecamatan betara (Y)). Hal ini dilakukan dengan cara membandingkan nilai probabilitas dengan taraf signifikansi $5 \%$. Perbandingan dilakukan dengan criteria apabila nilai probablitas lebih kecil 
dibandingkan dengan taraf signifikansi $5 \%$ maka variabel bebas memiliki pengaruh teradap variabel terikat sedangkan apabila nilai probablitas lebih besar dibandingkan dengan taraf signifikansi $5 \%$ maka variabel bebas tidak memiliki pengaruh teradap variabel terikat Koefisien regresi pada setiap variabel menunjukkan pengertian sebagai berikut:

\section{Variabel produksi (PRO)}

Berdasarkan hasil perhitungan diketahui nilai probabilitas variabel bebas PRO adalah sebesar 0.0001. Nilai tersebut lebih kecil dibandingkan dengan taraf signifikansi $5 \%$. Hal ini berarti variabel bebas PRO memiliki pengaruh terhadap variabel bebas Y.

\section{Variabel biaya produksi (BP)}

Berdasarkan hasil perhitungan diketahui nilai probabilitas variabel bebas BP adalah sebesar 0.0000. Nilai tersebut lebih kecil dari taraf signifikansi 5\%. Hal ini berarti variabel BP memiliki pengaruh terhadap variabel Y.

\section{Variabel penggunaan tenaga kerja (PTK)}

Berdasarkan hasil perhitungan diketahui nilai probabilitas variabel bebas PTK adalah sebesar 0.0345 . Nilai tersebut lebih kecil dari taraf signifikansi 5\%. Hal ini berarti variabel PTK memiliki pengaruh terhadap variabel Y.

\section{Analisis ekonomi}

Berdasarkan hasil regresi linier berganda, koefisien regresi variabel produksi bernilai 3879,163 dan bertanda positif. Hal ini berarti apabila terjadi kenaikan produksi sebesar 1 bungkus maka pendapatan pengusaha keripik tempe akan mengalami peningkatan sebesar Rp. 3879,163. Temuan ini sesuai dengan teori yang dikemukan oleh Wasi (2017) yang menjelaskan bahwa jumlah input produksi akan mempengaruhi jumlah output produksi sehingga output produksi yang akan dijual menjadi lebih banyak sehingga pendapatan produsen akan meningkat.

Koefisien biaya produksi memiliki koefisien 2.823281 dan bertanda positif. Hal ini berarti apabila terjadi peningkatan biaya produksi sebesar Rp.1000 maka pendapatan akan meningkat sebesar Rp. 2823,281 . Temuan ini bertentangan dengan teori yang menjelaskan bahwa peningkatan biaya produksi akan menurunkan pendapatan. Pertentangan ini disebabkan karena biaya produksi digunakan untuk membeli input bahan baku produksi yang lebih banyak lagi sehingga output yang dihasilkan menjadi lebih banyak. Banyaknya output yang dihasilkan menyebabkan jumlah output yang dijual pun akan semakin banyak. Semakin banyak jumlah out yang mampu dijual oleh produsen maka semakin tinggi pendapatan yang diperoleh oleh produsen.

Koefisien penggunaan tenaga kerja memiliki nilai sebesar 954569.2 dan bernilai positif. Hal ini berarti produsen yang menggunakan tenaga kerja dalam proses produksi keripik tempe memiliki pendapatan lebih tinggi Rp. 954.569,2 dibandingkan dengan produsen yang tidak menggunakan tenaga kerja dalam proses produksi. Dikarenakan kebanyakan dari produsen pengusaha keripik tempe menggunakan anggota keluarga sendiri untuk membantu dalam proses produksi maka biaya produksi keripik tempe 
mampu untuk ditekan. Hal ini menjadikan biaya produksi menjadi semakin efisien. Penggunaan tenaga kerja mampu meningkatkan jumlah output sehingga pendapatan yang menggunakan tenaga kerja akan meningkat pula

\section{KESIMPULAN DAN SARAN \\ Kesimpulan}

Karakterisitik sosial pengusaha keripik tempe didominasi oleh umur 39-50 tahun yaitu sebear 50\%. Tingkat pendidikan terbanyak adalah SMA yaitu sebesar $55 \%$. Jumlah tanggungan pengusasa keripik tempe sebesar $50 \%$ berjumlah $4-5$ orang. $15 \%$ dari pengusaha keripik tempe memiliki pengalaman kerja 17-20 tahun. 30\% pengusaha keripik tempe memproduksi keripik tempe sebanyak 1.701-2.050 bungkus dan 2.4012.750 bungkus. $45 \%$ pengusaha keripik tempe memiliki pendapatan Rp 12.500 .000 Rp.14.000.000. Berdasarkan hasil regresi linier berganda, variabel pengaruh produksi, biaya produksi dan penggunaan tenaga kerja secara bersama-sama maupun parsial memiliki pengaruh terhadap pendapatan pengusaha keripik tempe di Kecamatan Betara.

\section{Saran}

Karakteristik dalam penelitian ini hanya mencakup pada segi sosial para pengusaha keripik tempe di Kecamatan Betara. Pada masa yang akan datang apabila terdapat akademisi yang ingin meneliti penelitian dengan tema yang sama diharapkan dan dianjurkan memasukkan karakteristik pada segi ekonomi untuk menghasilkan kajian empiris yang lebih sempurna lagi. Faktor-faktor yang digunakan dalam penelitian ini adalah produksi (PRO), biaya produksi (BP) dan penggunaan tenaga kerja (PTK) sebagai variabel bebas yang mempengaruhi variabel terikat pendapatan pengusaha keripik tempe (Y) maka sebaiknya dimasa yang akan datang untuk menggunakan variabel bebas lainnya di luar dari variabel bebas penelitian ini untuk menghasilkan kajian empiris yang lebih sempurna.

\section{DAFTAR PUSTAKA}

Adiningsih, S . (2009). Ekonomi Mikro. BPPE: Yogyakarta

Amir. (2009). Metodologi Penelitian Ekonomi dan Penerapannya. Penerbit IPB PRESS: Bogor.

Artaman, D.M.A. (2015). Analisis Faktor-Faktor yang mempengaruhi pendapatan pedagang pasar seni sukawati di Kabupaten Gianyar. Tesis-FE UNUD. Universitas Udayana: Denpasar.

Asruni. (2012). Faktor-Faktor yang Mempengaruhi Pendapatan Usaha Kecil dan Menengah (UKM) di Kabupaten Hulu Sungai Selatan Provinsi Kalimantan Selatan. Jurnal 17 Kindai No.8 Tahun 2012 Hal. 362-380: Kalimantan Selatan.

Atun, N.I. (2016). Pengaruh Modal, Lokasi, dan Jenis Dagangan Terhadap Pendapatan Pedagang Pasar Prambanan Kabupaten Sleman. Skripsi FE-UNY. Universitas Negeri Yogyakarta: Yogyakarta.

Bodieono, (2002).Ekonomi Mikro: Seri Sinopsis pengantar Ilmu Ekonomi No,1.Edisi 2.BPPE: Yogyakarta. 
Firdaus, M. (2011). Ekonometrika Suatu Pendekatan Aplikatif. PT. Bumi Aksara: Jakarta

Kelana, S. (1996). Teori ekonomi mikro. Rajawali Pres: Jakarta

Ma'arif, S. (2013). Analisis Faktor-Faktor yang mempengaruhi Pendapatan Pedagang Pasar Bandarjo Ungaran Kabupaten Semarang. Skripsi-FE UNS. Universitas Negeri Semarang: Semarang

Nazir, M. (2014). Metode Penelitian. Bogor: Ghalia Indonesia.

Rusanti, D. (2014). Determinan Pendapatan Usaha Mikro, Kecil, dan Menengah (UMKM) Sektor Industri Pengolahan di Kabupaten Jember. Artikel Ilmiah Mahasiswa 2014 hal 1-7. Universitas Jember: Jember.

Sugiono.(2004). Statistik Menjadi Mudah 17. Elex Media Kompetindo. Jakarta

Sugiyono.(2011). Metode Penelitian Kuantitatif, Kualitatif dan R\&D. Penerbit Alfabeta: Bandung.

Sukirno, S.(1985). Ekonomi Pembangunan. Bima Grafik: Jakarta.

Suparmoko. (2002). Ekonomi Publik Untuk Keuangan san Pembangunan Daerah. Andi: Yogyakarta

Tasman, Aulia. (2007). Ekonomi Produksi Teori dan Aplikasi. Chandra Pratama: Jakarta

Umar, Husien. (2005).Metode Penelitian Untuk Skripsi dan Tesis Bisnis.PT. Raja Grafindo Persada: Jakarta

Keputusan Menteri Keuangan Nomor : 316/KMK.016/1994 tanggal 27 Juni 1994

Undang-Undang Nomor 20 Tahun 2008 tentang Usaha Mikro, Kecil, dan Menengah (UU UMKM) 